\title{
Penelitian Kendali Acak Terbuka Terhadap Efektifitas dan Keamanan Cairan Elektrolit Rumatan pada Neonatus dan Anak (KAEN 4B ${ }^{\circledR}$ vs N/4D5)
}

\author{
M. Juffrie
}

Cairan rumatan sangat dibutuhkan oleh tubuh kita untuk memelihara keseimbangan hemodinamik, apalagi pada pasien neonatus dan anak. Cairan rumatan dengan kecukupan elektrolit esensial sangat berperan penting menunjang keseimbangan cairan dan elektrolit sehari-hari. Oleh karena itu dibutuhkan suatu bentuk cairan yang mengandung kecukupan air dan elektrolit tersebut. Penelitian ini bertujuan melihat dan mengetahui lebih jauh apakah sediaan cairan rumatan baru (KAEN $4 B^{\circledR}$ ) yang telah dipasarkan dapat memenuhi kecukupan elektrolit dan aman dipakai dibandingkan dengan cairan rumatan yang biasa digunakan pada pasien neonatus dan anak, yaitu cairan $\mathrm{NaCl} 0.225 \%$, D5 atau (N/4-D5).

Penelitian kendali acak terbuka ini dilakukan terhadap 44 subyek yang terbagi 22 subyek pada kelompok kasus dengan cairan elektrolit rumatan (KAEN 4B ${ }^{\circledR}$ ) dan 22 subyek lainnya pada kelompok kontrol dengan (N/4-D5). Tidak didapatkan suatu perbedaan yang bermakna dari kadar natrium dan kalium serum antara kedua kelompok setelah 6-8 jam perlakuan; sedangkan kadar kalium di dalam urin tampak lebih sedikit pada kelompok kontrol. Analisa gas darah tak tampak ada perbedaan bermakna sebelum dan setelah perlakuan pada kedua kelompok namun kadar pCO2 lebih tinggi pada kelompok kontrol. Kreatinin serum tak ada perbedaan pada kedua kelompok tetapi terjadi penurunan setelah perlakuan 6-8 jam. Kadar glukosa terdapat penurunan setelah perlakuan terutama pada kelompok kontrol. Tidak didapatkan suatu reaksi efek samping atau reaksi anafilaksi pada kedua kelompok. Hasil penelitian ini menunjukkan bahwa pemakaian cairan elektrolit rumatan baru yang beredar di pasaran KAEN 4B ${ }^{\circledR}$ dapat menjaga kadar elektrolit terutama $\mathrm{Na}$ dan $\mathrm{K}$ setelah 6-8 jam puasa, aman dipakai dan bisa diterima dengan baik pada neonatus dan anak bila dibandingkan cairan N/4-D5.

Kata kunci: cairan rumatan, penelitian uji klinis acak terbuka

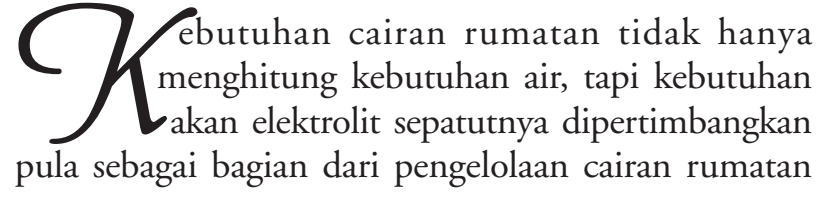

Alamat Korespondensi:

Dr. M. Jurie, Ph.D., SpA(K).

Bagian Ilmu Kesehatan Anak FK UGM RS Dr. Sardjito.

Jl Kesehatan No. 1. Yogyakarta. secara keseluruhan terutama pada neonatus dan anak. Pada anak sehat kebutuhan cairan bisa dipenuhi secara oral, ${ }^{1}$ akan tetapi pada pasien berat yang dirawat inap, cara oral bisa tidak efektif. Karena itu pemberian secara intravena perlu dipertimbangkan sebagai jalan alternatif untuk dalam mempertahankan pemenuhan kebutuhan cairan dan elektrolit rumatan. ${ }^{2}$ Banyak faktor yang akan mempengaruhi kebutuhan cairan dan elektrolit secara langsung dan tentu saja akan mempengaruhi jumlah 
cairan dan elektrolit. Faktor-faktor seperti bertambahnya atau berkurangnya cairan di paru dan kulit, kehilangan melalui urin dan feses, adanya kehilangan cairan akibat demam, hiperventilasi, aktifitas yang berlebihan, diare dan poliuri, menyebabkan anak memerlukan cairan dan elektrolit secara intravena. ${ }^{3}$

Untuk mencapai tujuan kecukupan cairan dan elektrolit rumatan perlu persiapan cairan dan elektrolit yang sesuai. ${ }^{4}$ Sediaan cairan rumatan neonatus dan anak yang sekarang lazim dipakai mempunyai kadar natrium terlalu tinggi serta kalium terlalu rendah (N/4-D5). Sebagai alternatif sekarang telah dikembangkan cairan elektrolit rumatan yang mengandung glukosa $37.5 \mathrm{gr} /$ $\mathrm{L}, \mathrm{Na}^{+} 30 \mathrm{meq} / \mathrm{L}, \mathrm{K}^{+} 8 \mathrm{meq} / \mathrm{L}$ dan $\mathrm{Cl}^{-} 28 \mathrm{meq} / \mathrm{L}$ serta laktat $10 \mathrm{mMol} / \mathrm{L}$. Cairan ini mirip dengan cairan $\mathrm{NaCl}$ $0.225 \%$, 5\% dekstrose, dengan penambahan kalium lebih tinggi $(8 \mathrm{mEq} / \mathrm{L})$ dan kadar natrium lebih rendah (30 $\mathrm{mEq} / \mathrm{L})$ yang dapat memperkecil risiko pasien menjadi hipernatremia dan hipokalemia. ${ }^{5}$

Penelitian ini bertujuan untuk mengetahui apakah cairan elektrolit rumatan KAEN $-4 \mathrm{~B}$ efektif mengurangi risiko hipernatremia dan hipokalemia dan seberapa jauh bisa diterima atau aman diberikan pada neonatus dan anak.

\section{Cara penelitian}

Penelitian dilakukan di RS Dr Sardjito, Bagian Ilmu Kesehatan Anak, Yogyakarta, pada bulan Januari sampai dengan Oktober 2003.

Subyek yang diteliti adalah anak usia di bawah 14 tahun, pasien dipuasakan lebih dari 6-8 jam untuk suatu pemeriksaan tertentu (USG atau endoskopi), pasien praoperasi atau yang akan dilakukan operasi yang dipuasakan lebih dari 6-8 jam. Orang tua atau keluarga pasien telah menyetujui dan menandatangani in form concent. Sedangkan pasien akan dikeluarkan dari penelitian apabila terdapat kelainan renal, malnutrisi berat, bayi prematur, dengan kelainan kongenital, dan terdapat kelainan gastrointestinal seperti kolostomi, obstruksi usus.

Protokol penelitian telah disyahkan dan disetujui oleh komite etik Fakultas Kedokteran Universitas Gadjah Mada, Indonesia. Setelah dilakukan random alokasi pada subyek yang terpilih sesuai kriteria inklusi dan eksklusi maka pasien dibagi dua kelompok yaitu kelompok yang mendapat cairan elektrolit rumatan $\left(\right.$ KAEN $\left.4 \mathrm{~B}^{\circledR}\right)$ dan yang akan mendapat cairan $\mathrm{NaCl}$
0.225\%, D5 atau (N/4-D5) sebagai kelompok kontrol. Dipilihnya kasus pasien puasa selama 6-8 jam untuk menghindari adanya masukan cairan dan elektrolit peroral serta sedapat mungkin menjaga homogenitas subyek yang diteliti. Sebelum perlakuan pasien diperiksa darah perifer, elektrolit Natrium dan Kalium (dalam darah dan urin) serta analisis gas darah. Selanjutnya kelompok perlakuan diberi cairan intravena dengan cairan elektrolit rumatan (KAEN $4 \mathrm{~B}^{\circledR}$ ) sedangkan kelompok kontrol diberi cairan $\mathrm{NaCl}$ $0.225 \%$, D5 atau (N/4-D5). Kebutuhan cairan rumatan dihitung individual berdasarkan luas permukaan tubuh pasien dan diberikan infus rumatan dengan tetesan 25-40 tetes dengan infus set dewasa. Tambahan makanan per oral tidak diperkenankan sama sekali. Selama perlakuan semua reaksi yang timbul akibat perlakuan dicatat. Setelah $6-8$ jam kemudian semua kelompok perlakuan akan diperiksa kembali elektrolit $\mathrm{Na}^{+}$dan $\mathrm{K}^{+}$(darah dan urin) dan analisa gas darahnya. Data-data seperti: data demografi, diagnosis pasien dan data klinis lainnya telah ada dan dicatat sebelum dilakukan perlakuan.

\section{Analisis data}

Data di analisa menggunakan program komputer SPSS for Windows versi 10. Analisa banding antara kadar $\mathrm{Na}$ dan K (darah dan urin) dan analisa gas darah pada kedua kelompok sebelum dan sesudah perlakuan digunakan cara non parametrik Wilcoxon Rerata Whitney Test untuk distribusi data tidak normal. Sedangkan perbedaan kadar elektrolit serta analisa gas darah sebelum dan sesudah perlakuan pada obyek yang sama di analisa dengan paired student-T test. Data efek samping di analisis dengan cara chi-square.

\section{Hasil}

Empat puluh empat subyek yang memenuhi kriteria inklusi dan eksklusi telah mengikuti penelitian ini sampai selesai. Terbagi menjadi 22 kelompok perlakuan dan 22 kelompok kontrol. Subyek laki-laki lebih banyak dibanding perempuan, meskipun secara statistik tak berbeda bermakna (Tabel 1). Usia subyek berkisar antara 1 sampai 13 tahun dan tidak ada perbedaan yang bermakna umur antara kelompok perlakuan dan kelompok kontrol (Tabel 2). 
Tabel 1. Distribusi Jenis Kelamin

\begin{tabular}{lcccc}
\hline \multirow{2}{*}{ Jenis kelamin } & \multicolumn{2}{c}{ Kelompok } & Total & $\mathrm{p}$ \\
\cline { 2 - 3 } & Kasus & Kontrol & & \\
\hline Laki - laki & 16 & 13 & 29 & \\
Perempuan & 6 & 9 & 15 & 0,52 \\
\hline Jumlah & 22 & 22 & 44 & \\
\hline
\end{tabular}

Tabel 2. Distribusi Umur

\begin{tabular}{cccc}
\hline Kelompok & Rerata & $\begin{array}{c}\text { minimal }- \text { maksimal } \\
\text { (tahun) }\end{array}$ & $\mathrm{p}$ \\
\hline Kasus & $6,23 \pm 4,30$ & $1-13$ & 0,70 \\
Kontrol & $6,64 \pm 3,16$ & $1-12$ & \\
\hline
\end{tabular}

\section{Elektrolit darah}

Kadar natrium sebelum perlakuan normal pada kedua kelompok dan tidak berbeda bermakna diantara keduanya 137,09 $\pm 2,94$ dan $136,50 \pm 3,94$. $(p=0,4)$. Demikian juga kadar Natrium sesudah perlakuan adalah dalam batas normal dan tidak berbeda bermakna diantara kedua kelompok 137,04 $\pm 3,19$ dan 136,31 $2.8(\mathrm{p}=0,7)$ (Gambar 2). Sedangkan kadar natrium pada kelompok kasus sebelum dan sesudah perlakuan tidak perbedaan yang bermakna, demikian juga pada kelompok kontrol $(\mathrm{p}=0.7 \mathrm{dan} 0,9)$.

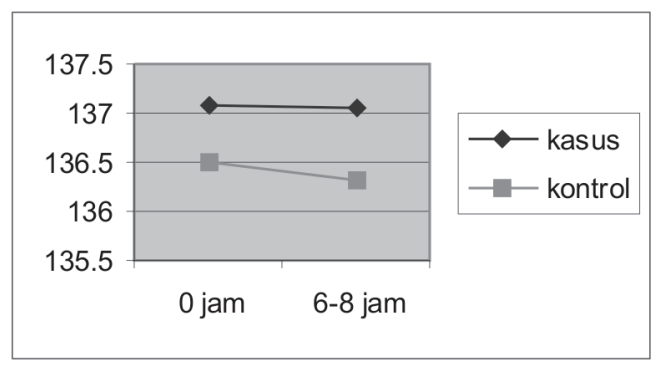

Gambar 2. Kadar natrium dalam darah

Kadar kalium sebelum perlakuan normal pada kedua kelompok dan tidak ada perbedaan bermakna antara keduanya 3,89 $\pm 0,58$ dan 4,01 $\pm 0,95(p=0,4)$. Setelah perlakuan terjadi kenaikan rata-rata kadar

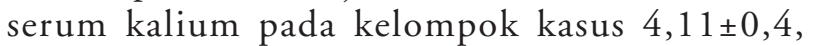
(Gambar 3) meskipun secara statistik tidak bermakna $(\mathrm{p}=0,06)$. Sedangkan pada kelompok kontrol tidak didapatkan perubahan yang berarti 4,00 $\pm 0,37(\mathrm{p}=0,9)$

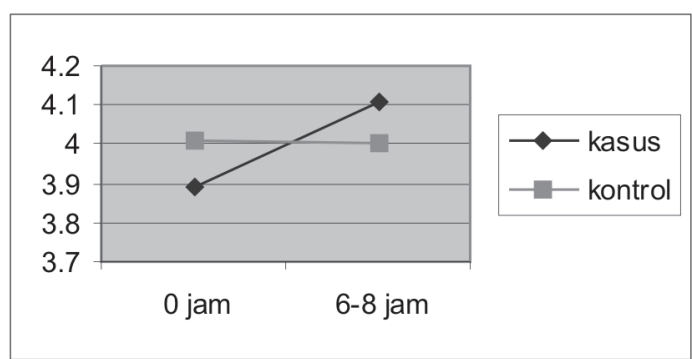

Gambar 3. Kadar kalium dalam darah

Kadar glukosa sebelum perlakuan antara kelompok kasus dan kontrol normal dan tak ada perbedaan antara keduanya 95,54 $\pm 15,4$ dan 98,19 $\pm 32,65(\mathrm{p}=0.3)$. Kadar glukosa setelah perlakuan terdapat penurunan yang bermakna baik pada kelompok kasus 82,27 \pm $9,07(\mathrm{p}=0,02)$ dan juga pada kelompok kontrol 78,23 $\pm 26,0(\mathrm{p}=0,03)$, tetapi tak ada perbedaan bermakna diantara kedua kelompok $(\mathrm{p}=0,9)($ Gambar 4).

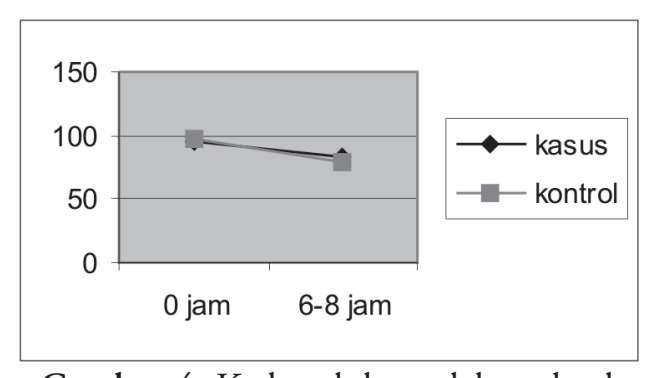

Gambar 4. Kadar glukosa dalam darah

Kadar kreatinin darah normal pada sebelum perlakuan maupun sesudah perlakuan pada kelompok kasus dan kontrol dan didapatkan perbedaan yang bermakna sebelum dan sesudah perlakuan $(\mathrm{p}=0,005$; $\mathrm{p}$ $=0,001)$ akan tetapi tidak didapatkan perbedaan diantara kedua kelompok $0,5 \pm 0,12 ; 0,52 \pm 0,17 ; 0,43 \pm 0,12$; $0,47 \pm 0,13 ; p=0,8 ; p=0,13)($ Gambar 5)

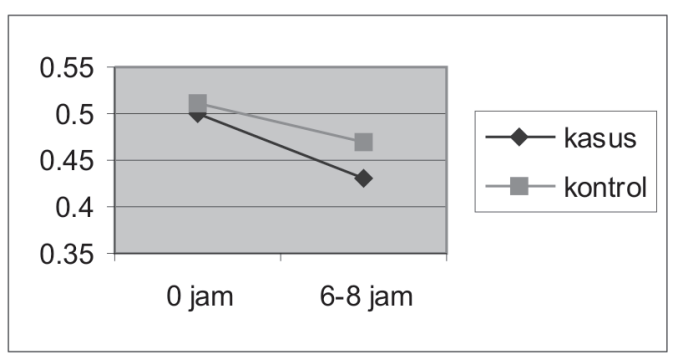

Gambar 5. Kadar kreatinin dalam darah 
Analisa gas darah pada kedua kelompok sebelum perlakuan normal, sedangkan sesudah perlakuan terdapat peningkatan $\mathrm{Pa} \mathrm{O}_{2}$ pada kelompok kasus, meskipun secara statistik tidak bermakna (Tabel 3). Sedangkan kadar $\mathrm{Pa} \mathrm{O}_{2}$ sebelum perlakuan lebih tinggi secara bermakna pada kelompok kasus dibanding kontrol demikian juga saturasi $\mathrm{O}_{2}$ lebih tinggi pada kelompok kasus, kadar $\mathrm{Pa}_{2} \mathrm{CO}_{2}$ sesudah perlakuan lebih tinggi secara bermakna pada kelompok kontrol dibanding kelompok kasus. (Tabel 3)

Kadar Natrium dalam urin sebelum perlakuan lebih tinggi dibanding kadar Natrium sesudah perlakuan pada kedua kelompok tetapi hanya pada kelompok kontrol yang lebih tinggi secara bermakna (lihat Tabel 4). Sedangkan kadar Natrium kelompok kasus dan kontrol baik sebelum maupun sesudah perlakuan tidak ada perbedaan yang bermakna (lihat Tabel 4 dan Gambar 6).

Kadar kalium dalam urin lebih tinggi pada kelompok kontrol dibanding kasus sebelum dan sesudah perlakuan meskipun secara statistik tidak bermakna. Kadar kalium urin sesudah perlakuan pada kelompok kontrol lebih rendah dibanding sebelum perlakuan meskipun secara statistik tidak bermakna (Tabel 4, Gambar 7)

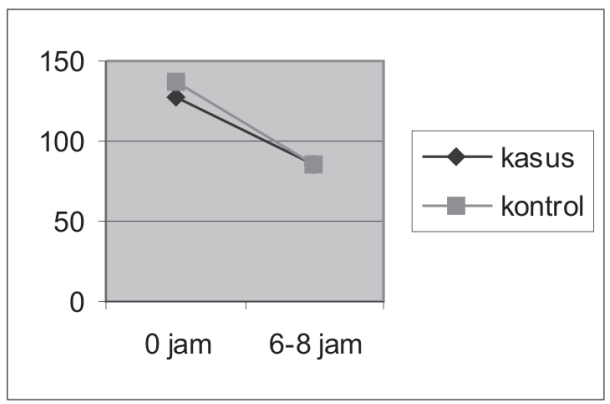

Gambar 6. Kadar Natrium dalam urin

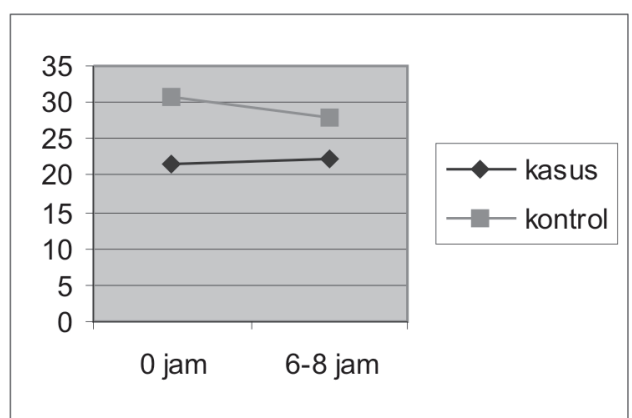

Gambar 7. Kadar kalium dalam urin

Tidak didapatkan reaksi allergi ataupun anafilaksis pada saat pemberian cairan baik pada kelompok kontrol maupun kasus

Tabel 3. Evaluasi Analisis Gas Darah

\begin{tabular}{|c|c|c|c|c|}
\hline \multirow{2}{*}{ Parameter } & \multirow{2}{*}{ Kelompok } & \multicolumn{2}{|c|}{ Evaluasi (jam) } & \multirow{2}{*}{$\mathrm{p}$} \\
\hline & & 0 & $6-8$ & \\
\hline \multirow{3}{*}{$\mathrm{HCO}_{3}$} & Kasus & $18,75 \pm 2,96$ & $18,38 \pm 3,5$ & 0,6 \\
\hline & Kontrol & $20,18 \pm 2,77$ & $21,05 \pm 4,2$ & 0,3 \\
\hline & & $\mathrm{p}=0,12$ & $\mathrm{p}=0,06$ & \\
\hline \multirow[t]{3}{*}{$\mathrm{PaO}_{2}$} & Kasus & $94,92 \pm 30,64$ & $111,91 \pm 72,66$ & 0,1 \\
\hline & Kontrol & $75,90 \pm 27,99$ & $88,96 \pm 28,79$ & 0,3 \\
\hline & & $\mathrm{p}=0,02$ & $\mathrm{p}=0,04$ & \\
\hline \multirow{3}{*}{$\mathrm{PaCO}_{2}$} & Kasus & $29,66 \pm 4,7$ & $28,63 \pm 6,6$ & 0,9 \\
\hline & Kontrol & $32,73 \pm 4,6$ & $32,88 \pm 5,8$ & 0,4 \\
\hline & & $\mathrm{p}=0,054$ & $\mathrm{p}=0,03$ & \\
\hline \multirow[t]{3}{*}{ Base excess } & Kasus & $-5,08 \pm 3,4$ & $-5,32 \pm 3,4$ & 0,4 \\
\hline & Kontrol & $-4,16 \pm 2,4$ & $-3,58 \pm 2,9$ & 0,7 \\
\hline & & $\mathrm{p}=0,2$ & $\mathrm{p}=0,06$ & \\
\hline \multirow[t]{3}{*}{ Saturasi $\mathrm{O}_{2}$} & Kasus & $93,41 \pm 13,3$ & $93,06 \pm 15$ & 0,1 \\
\hline & Kontrol & $87,46 \pm 18,4$ & $94,65 \pm 8,22$ & 0,9 \\
\hline & & $\mathrm{p}=0,04$ & $p=0,3$ & \\
\hline \multirow[t]{3}{*}{$\overline{\mathrm{pH}}$ Darah } & Kasus & 7,42 & 7,42 & 0,8 \\
\hline & Kontrol & 7,40 & 7,40 & 0,5 \\
\hline & & $\mathrm{p}=0,3$ & $\mathrm{p}=0,1$ & \\
\hline
\end{tabular}


Sari Pediatri, Vol. 6, No. 2, September 2004

Tabel 4. Kadar Natrium dan Kalium Urin Kadar dalam urin

\begin{tabular}{|c|c|c|c|c|}
\hline & \multirow{2}{*}{ Kelompok } & \multicolumn{2}{|c|}{ Evaluasi (jam) } & \multirow[t]{2}{*}{$\mathrm{p}$} \\
\hline & & 0 & $6-8$ & \\
\hline \multirow{3}{*}{$\begin{array}{c}\text { Natrium } \\
\mathrm{mg} / \mathrm{dl})\end{array}$} & Kasus & $127,54 \pm 93,20$ & $85,68 \pm 60,4$ & 0,16 \\
\hline & Kontrol & $137,62 \pm 157,7$ & $85,97 \pm 47,7$ & 0,01 \\
\hline & & $\mathrm{p}=0,8$ & $\mathrm{p}=0,6$ & \\
\hline \multirow{3}{*}{$\begin{array}{l}\text { Kalium } \\
(\mathrm{mg} / \mathrm{dl})\end{array}$} & Kasus & $21,63 \pm 13,44$ & $22,29 \pm 22,9$ & 0,5 \\
\hline & Kontrol & $30,63 \pm 24,82$ & $27,84 \pm 29,7$ & 0,9 \\
\hline & & $\mathrm{p}=0,3$ & $\mathrm{p}=0,2$ & \\
\hline
\end{tabular}

\section{Diskusi}

Penelitian ini mempunyai tujuan untuk melihat apakah cairan elektrolit rumatan efektif dan aman dalam mencukupi kebutuhan elektrolit pada anak dan bayi, Dari hasil penelitian ini didapatkan bahwa cairan elektrolit rumatan ini cukup efektif .

Penelitian ini dilakukan pada anak umur termuda 1 tahun dan yang tertua 13 tahun ini berarti bahwa distribusi umur cukup lebar variasinya mulai dari bayi sampai anak-anak, sesuai dengan tujuan pembuatan cairan ini diharapkan bisa dipakai mulai bayi sampai anak-anak. Sedangkan distribusi jenis kelamin memang lebih banyak yang laki-laki dibanding perempuan, hal ini tidak mempengaruhi hasil karena jenis kelamin tidak mempengaruhi metabolisme pengaturan cairan dan elektrolit di dalam tubuh. ${ }^{6}$

Penelitian ini dilakukan pada anak yang dipuasakan sebagai prosedur sebelum operasi. Perlakuan ini dimaksudkan untuk memperoleh suatu keadaan masukan cairan dan elektrolit berkurang sehingga dampak pemberian cairan bisa diukur lebih objektif karena tidak terganggu oleh masukan per oral.

Dari hasil kadar elektrolit natrium ternyata tidak ada perubahan yang mencolok setelah dipuasakan 6 - 8 jam, hal ini sesuai dengan fisiologi cairan bahwa pemberian cairan elektrolit rumatan $(\mathrm{Na})$ akan memelihara kadar $\mathrm{Na}$ dalam batas normal. Meskipun demikian apabila dilihat hasil kadar $\mathrm{Na}$ urin ternyata pada kelompok kontrol lebih rendah setelah dipuasakan. Hal ini dimungkinkan bahwa reabsorbsi Na pada saat puasa pada kelompok ini lebih besar untuk menstabilkan kadar $\mathrm{Na}$ dalam serum, jadi sebagai proses kompensasi fisiologi pada saat kadar $\mathrm{Na}$ serum sudah mulai turun. ${ }^{7}$ Pada kelompok kasus juga terjadi hal yang sama dan tidak ada perbedaan yang bermakna.

Kadar kalium dalam serum pada kedua kelompok pada saat sebelum perlakuan normal. Namun setelah perlakuan, kadar kalium pada kelompok kasus terjadi kenaikan absolut sebesar $0,22 \mathrm{mEq} / \mathrm{L}$ meskipun secara statistik tidak bermakna. Secara klinis cukup bermakna dengan perbedaan $0,22 \mathrm{mEq} / \mathrm{L}$ ini kadar kalium menunjukkan perubahan total kalium tubuh secara menyeluruh dan berarti sudah ada masukan kalium ke dalam tubuh walau sedikit. Hal ini dikuatkan lagi dari data bahwa kadar kalium urin pada kelompok kontrol berkurang sesudah puasa yang menunjukkan adanya reabsorpsi berlebih sedangkan pada kelompok kasus tidak didapatkan.

Kadar glukosa serum ternyata ada penurunan yang bermakna sebelum dan sesudah diberikan perlakuan. Tidak ada perbedaan yang bermakna di antara dua kelompok. Meskipun demikian jika kita nilai absolut delta kadar glukosa sebelum dan sesudah perlakuan kelompok kasus lebih kecil dibanding kelompok kontrol (13.27 dibanding 19.96). Hal ini menunjukkan bahwa kecukupan glukosa pada cairan elektrolit rumatan cukup memenuhi kebutuhan glukosa serum.

Kadar kreatinin darah terdapat penurunan yang bermakna sebelum dan sesudah perlakuan, meskipun tidak bermakna diantara kedua kelompok. Kadar kreatinin serum menunjukkan fungsi ginjal terutama fungsi filtrasi $(8,9)$. Apabila terjadi penurunan fungsi filtrasi maka akan terjadi kenaikan kadar kreatinin serum. Fungsi filtrasi ginjal dipengaruhi oleh jumlah cairan dan elektrolit yang masuk ke ginjal. Penurunan kadar kreatinin yang masih dalam batas normal menandakan kecukupan cairan dan elektrolit dalam serum masih baik. Pada penelitian ini pemberian cairan elektrolit rumatan bisa memelihara kecukupan tersebut. 
Analisis gas darah pada penelitian ini tidak terjadi perubahan yang berarti baik pada kelompok kasus maupun kontrol, hal ini menunjukkan kecukupan cairan sehingga tak terjadi dehidrasi pada subyek penelitian yang menyebabkan perubahan asam dan basa darah. Meskipun demikian kadar $\mathrm{pCO}_{2}$ pada kelompok kontrol lebih tinggi secara bermakna dibanding kelompok kasus, ini menunjukkan adanya penurunan $\mathrm{K}$ pada kelompok kontrol yang cukup banyak sehingga fungsinya digantikan kadar $\mathrm{H}+$ yang seharusnya mengikat $\mathrm{CO}_{2}$. Hal ini mengakibatkan kadar $\mathrm{CO}_{2}$ lebih tinggi pada kelompok kontrol, dapat dikatakan bahwa cairan elektrolit rumatan mencukupi kebutuhan $\mathrm{K}+$.

Pada penelitian ini tidak didapatkan reaksi efek samping pada kedua kelompok, maka pemberian cairan elektrolit rumatan bisa diterima dan di toleransi oleh subyek.

\section{Kesimpulan}

Telah dilakukan penelitian kendali acak terbuka terhadap efektifitas dan keamanan cairan elektrolit rumatan pada neonatus dan anak (KAEN 4B ${ }^{\circledR}$ dibandingkan N/4-D5). Dari penelitian ini menunjukkan bahwa pemberian cairan elektrolit rumatan baru (KAEN 4B ${ }^{\circledR}$ ) dalam waktu 6-8 jam cukup efektif dan aman dalam memenuhi kebutuhan cairan dan elektrolit pada bayi dan anak. Penelitian seperti ini dengan besar sampel yang lebih banyak dan metoda yang lebih baik diperlukan kemudian hari.

\section{Daftar Pustaka}

1. Walser, M. Phenomenological analysis of electrolyte homeostasis. Dalam: In The Kidney: Physiology and Pathophysiology Seldin D.W., Giebisch G. penyunting. Edisi ke-2. New York; Traven, 1992. h. 31-44

2. Graber, M.A. Kelainan elektrolit, dan metabolik: muntah, diare dan dehidrasi. Dalam: Terapi cairan elektrolit, dan metabolik. cetakan 1: Jakarta; Farmedia, 2002. h. 15-24

3. Graber, M.A. Kelainan elektrolit dan metabolit: syok. Dalam: Terapi cairan elektrolit, dan metabolit. cetakan 1. Jakarta; Farmedia, 2002. h. 1-14.

4. M. Heer, F. Balsch, J. Kropp, R. Gerzer, C. Drummer. High dietary chloride consumption may not induce body fluid retention in humans. Am J Physiol Renal Physiol, 2000; 278:F585-95

5. Giebisch G. Renal potassium transport: mechanisms and regulation. Am J Physiol Renal Physiol. 1998: 274:F81733

6. Robson, A.M. The pathophysiology of body fluid. Dalam: Text book of Pediatrics, Nelson W.E penyunting. Edisi ke-11. Philadelphia: W.B. Saunders Company. 1983. h. 206-28

7. Drummer, C, Gerzer, R, Heer M,. Effect of an acute saline infusion on fluid and electrolyte metabolism in humans. Am J Physiol Renal Physiol, 1992:F 744-54

8. Maren, T.H. Carbonic anhydrase: chemistry, physiology, and inhibition. Physiol Rev, 1967; 47:595-781

9. Unwin, R, Stidwell, S., Taylor, S, Capasso. G. The effects of respiratory alkalosis and acidosis on net bicarbonate flux along the rat loop of Henle in vivo. Am J Physiol Renal Physiol. 1997; 273:F698-705 